\title{
Solid Waste Management Challenges in Urban Areas of Ghana: A Case Study of Bawku Municipality
}

\author{
Nang Biyogue Douti ${ }^{*}$, Samuel Kojo Abanyie ${ }^{1}$, Steve Ampofo ${ }^{1}$, Senyo Komla Nyarko² \\ ${ }^{1}$ Faculty of Applied Sciences, University for Development Studies, Department of Earth and Environmental Sciences, Navrongo \\ Campus, Navrongo, Ghana \\ ${ }^{2}$ Wastelandfills Company Ltd., Koforidua, Ghana \\ Email: *binado1@yahoo.fr
}

How to cite this paper: Douti, N.B., Abanyie, S.K., Ampofo, S. and Nyarko, S.K. (2017) Solid Waste Management Challenges in Urban Areas of Ghana: A Case Study of Bawku Municipality. International Journai of Geo- sciences, 8, 494-513.

https://doi.org/10.4236/ijg.2017.84026

Received: November 26, 2016

Accepted: April 15, 2017

Published: April 18, 2017

Copyright $\odot 2017$ by authors and Scientific Research Publishing Inc. This work is licensed under the Creative Commons Attribution International License (CC BY 4.0).

http://creativecommons.org/licenses/by/4.0/

\begin{abstract}
This study was conducted in the Bawku Municipality of the Upper East, Ghana, with the view to assessing the factors that impede the management of solid waste. Questionnaires were submitted to 150 randomly selected households, while face-to-face semi-structured interviews were conducted with the municipal Waste Management Department and a private waste management company, Zoomlion Ghana Ltd. Data collected included components of solid waste generated, waste collection, transportation and final disposal methods, the challenges confronting waste management institutions, and respondents' knowledge and perceptions of the waste management system and their attitudes towards it. Components of wastes generated were organic waste, paper waste and plastics. Factors that adversely affected waste collection and transportation systems were the inadequate supply of waste collection containers, the existence of a weak waste transportation system and a low patronage of the door-to-door collection method. The study showed that the municipal landfill did not meet the required standard. The results also revealed the lack of public awareness on issues regarding waste and lack of a participatory approach that makes the people an active stakeholder in the waste management system. This situation accounted for indiscriminate disposals of waste by most respondents who viewed the issue of waste management as the exclusive responsibility of the local government. The study further showed that the waste management institutions were faced with financial difficulties, understaffing and poor logistics and nature of roads, and social constraints. The study therefore suggests the development of a strategic plan for efficient waste management which revolves around these findings.
\end{abstract}

\section{Keywords}

Solid Waste Management, Urban Areas, Developing Countries, Ghana 


\section{Introduction}

In countries around the world, one major environmental problem that confronts municipal authorities is solid waste disposal [1]. The high increase in human population, its associated increase in urbanization and increase in economic activities has made the negative impact of solid waste management very noticeable in towns and cities around the world [2]. In developing countries in particular, the waste produced by burgeoning cities is overwhelming local authorities and national governments alike [3] [4] as accumulations of waste outstrip its control.

Several studies indicate that much of the municipal solid waste from developing countries is generated from households (55\% - 80\%), market areas $(10 \%$ $30 \%)$, and institutions among others [5] [6] [7]. Research has further indicated that wastes from these sources are highly heterogeneous in nature and have variable physical characteristics depending on their sources [8].

Despite the present concern of governments, organizations and individuals about solid waste management in Africa, it is still faced with more serious solid waste management problems with its accompanying negative health and environmental consequences [9]. Thus, the priority of a waste management system must always be the provision of a cleansing service which helps to maintain the health and safety of citizens and their environment [10]. It is therefore an undeniable fact that for humans to safeguard, control and promote the environment there must be some appropriate facilities for solid waste management. For in the absence of such facilities solid waste management will pose significant health problem [11].

In Ghana the rate of waste generation is $0.47 \mathrm{~kg} /$ person/day, which translates into about 12,710 tons of waste per day per the current population of 27,043,093. It is estimated that throughout the country only about $10 \%$ of solid wastes generated are properly disposed of [12]. Hence, large proportions (between 30 and 50 per cent) of the solid waste generated by the residents are never collected for disposal and end up dispersed on the streets, in drains and in streams [1] [13] thereby creating breeding grounds for disease spreading insects and vermin [14]. One of the drivers of these insanitary environmental conditions is the rapid urbanisation in Ghana which have resulted in waste accumulation and increased pressure on urban infrastructure and environmental services [11] [15]. The other factors that militate against efficient solid waste management are poor financing capacity of local authorities, low technical capacity for planning and management of solid waste [16], weak enforcement of environmental regulations [12]. In view of this background information on the country, it appears that the development of an in-depth database on solid waste management situations in each district, municipal and metropolitan assembly in Ghana will help formulate and implement effective solid waste management policy in the country. It is in line with this perspective that the present study was conducted in the Bawku Municipality of the Upper East Region of Ghana with the objective of assessing the solid waste management system in the municipality so as to under- 
stand the factors that impede its efficiency.

\section{Materials and Methods}

\subsection{Study Area}

The Bawku Municipality with its administrative capital at Bawku is one of the 13 Metropolitan, Municipal and District Assemblies (MMDAs) in the Upper East Region of Ghana. It is located at the north eastern corner of the region having an international boundary with Burkina Faso to the north, and other districts such as the Binduri district to the west, Garu-Tempane district to the south and Pusiga district to the east. It lies approximately between latitudes $11^{\circ} 10^{\prime} 29.7966^{\prime \prime} \mathrm{N}$ and $10^{\circ} 28^{\prime} 48.016^{\prime \prime} \mathrm{N}$ and longitudes $1^{\circ} 34^{\prime} 25.375^{\prime \prime} \mathrm{W}$ and $0^{\circ} 2^{\prime} 1.952^{\prime \prime} \mathrm{E}$ (Figure 1).

As with the rest the Upper East Region, the Bawku Municipality is part of the Savannah Agro-climatic zone of the country characterized by a unimodal rainfall regime of a pronounced dry (November - April) and wet seasons (May - October).

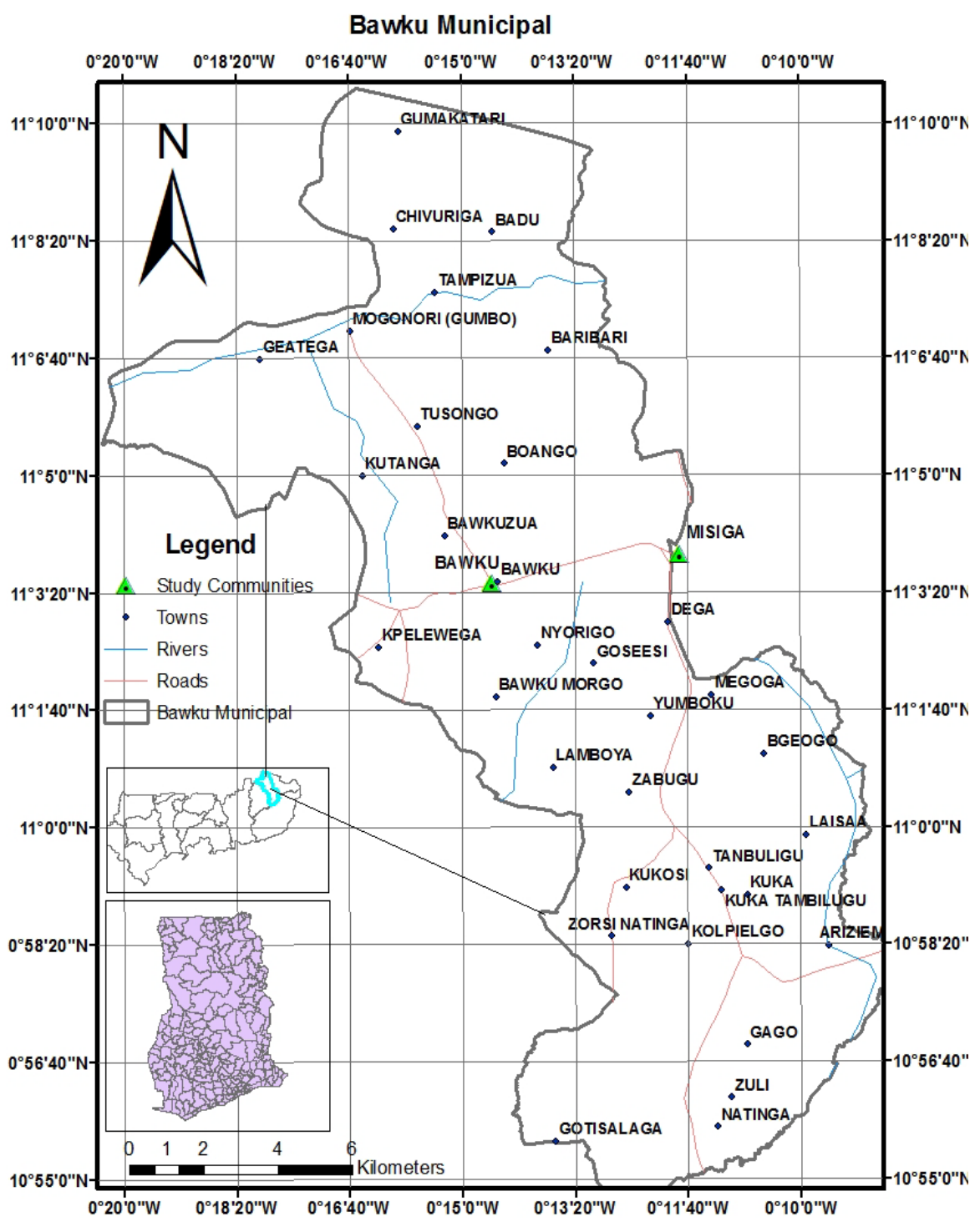

Figure 1. Map of the study area. 
The two seasons are influenced by two oscillating air masses. First is the warm, dusty and dry Harmattan air mass, which blows from the north easterly direction across the whole municipality from the Sahara Desert. From May to October marks the wet season characterised by a deep tropical maritime convection currents which provide the municipality with rains [17]. The single rainfall pattern has a mean annual rainfall figures ranging between 855 and $1269 \mathrm{~mm}$ [18].

The vegetation is mainly of the Sudan Savanna type consisting of open Savannah characterized by short scattered drought-resistant trees and grasses that gets burnt by bushfire or scorched by the sun during the long dry season. Soils in the municipality are generally of the savannah ochrosol type [17].

The Municipality is regarded as the commercial hub of the Upper East Region due to its strategic location and its proximity to the eastern Burkina Faso and Northern Togo as well as easy crossing into Mali and Niger. The state of environmental conditions in the municipality is improving, however, a lot more needs to be done [17].

\subsection{Research Approach and Data Collection}

A mixed methods research strategy, i.e. a research paradigm integrating both quantitative and qualitative research methods [19], was used for the collection and analysis of data in this study. The body of information collected included both secondary and empirical data. Secondary data were elicited from a critical literature review of scholarly articles on solid waste management and from government and private institutions namely, the Bawku municipal assembly's Town and Country Department, the Environmental Health Office/Waste Management Department, a private waste management company Zoomlion Ghana Limited, the Ministry of Food and Agriculture (MoFA) and the Upper East Regional office of Ghana Statistical Service.

The set of empirical data was generated through field work using questionnaires survey, face-to-face semi-structured interviews, and on-site visits of households, communal container collection sites, dumpsites, and landfill sites. This body of primary data was supplemented with information obtained from field observations. The data collected from these techniques were in connection with the methods used to collect and transport domestic solid waste, factors contributing to improper solid domestic waste management, and the consequences of improper waste management on health and the environment.

The questionnaires were administered to a representative sample of households selected from the population of households inventoried in the municipality. The questionnaires were used to collect information on the following aspects of the study: level of accessibility to information on solid waste management and environmental sanitation among respondents and the means through which this information was obtained, respondents' involvement in educating household on SWM/sanitation, the places and type of receptacles where household solid wastes were stored, the availability of skips and bins for storing waste, places of disposal of household waste, and the household people responsible for conveying waste 
to the dumping site and the distance and time covered to dispose of waste at the skip sites, the waste collection method and frequency at which household wastes were collected, and the subscription for household solid waste collection by the waste management company Zoomlion Ghana Limited. The other aspects of the data collected were related to respondents' involvement in educating household on SWM/sanitation, their perception of who is responsible for maintaining their surroundings clean, and the importance of work of the waste management personnel in the municipality. The questionnaires administered also included questions about the respondents' preparedness to make land available for construction of solid waste disposal sites in the municipality, and their perception of the effectiveness of waste management in the area.

Data collected from the interview technique were elicited from the following stakeholders: the Waste Management Department (WMD) and Environmental Health and Sanitation Unit (EHSU) of the municipality, the Zoomlion Company Limited, and the assemblymen (elected personalities of the communities in the municipalities who represent the people of the localities at the Municipal Assembly) of the area. The information collected from these key stakeholders included the types and quantity of waste generated in the municipality, the mode and frequency of waste collection in the area, and the level of provision of skips and dustbins in the area. The other aspects of the data collected were related to existing solid waste management practices in the municipality, the availability of needed resources for managing waste, and the challenges encountered in managing solid waste in the municipality. In addition to these data collection approaches, on-site visits of households, commercial areas, communal container collection sites, and dumpsites were carried out with the view to identifying the waste generation, collection, transportation, and disposal aspects of the whole waste management system in the municipality so as to provide a complete and cross-checked/reliable set of data to the research questions that guided the whole study.

\subsubsection{Procedure Used for Sampling Households}

The study population involved 150 households in the municipality randomly selected from a total number of 15,012 households according to sample size determination method suggested by [20] and [21]. The sample of households was selected randomly (simple and stratified) from the three Zonal Councils that sub-divided the municipality namely; Bawku Zonal Council, Mognori Zonal Council and Kuka/Zabugu Zonal Council. The concept of household in this study was referred to as a person or a group of persons, who live together in the same house or compound and share the same house-keeping arrangements [17]. Hence, in this study emphasis was placed on key respondents of households, i.e. household heads or their representatives who usually direct the daily handling of solid waste in the home. The questionnaires administered to the sample of households were subjected to a pre-test with the view to ensuring clear understanding of the questions and instructions contained therein by research assis- 
tants and respondents, minimising errors and non-response rate, and ensuring reliability and validity of data collected.

\subsubsection{Data Processing and Analysis}

Administered questionnaires were examined to check completeness, accuracy and consistency of responses in order to detect and eliminate errors. The data acquired from the study were analysed with MS-Excel and the Statistical Package for the Social Sciences (SPSS) software version 21.0.

\section{Results and Discussions}

\subsection{Demographic and Social Characteristics of Respondents}

The study results as displayed in Table 1 indicate that the majority of the household respondents were females $(56.3 \%$ ) as against $43.3 \%$ of males. This is an indication that more women are directly involved in household waste issues than men. This finding is consistent with previous research which established that in solid waste management, especially in developing countries, women play

Table 1. Profile of respondents.

Variable Respondents \%

\section{Gender}

Male

Female

Age-group

$21-30$

Education

SHS/O'Level

Occupation

Other

Monthly income level in Ghana Cedi (GHष)

$\mathrm{GH} \pitchfork 200$ 
a decisive role; and that waste management in households is basically a woman's job in these countries because they are directly concerned with household chores, [22] [23] [24]. Besides, this study result points to the fact that women play a pivotal role in waste collection in the Bawku municipality, hence the need to get them fully integrated in the development and successful implementation of a strategic plan for effective solid waste management and promotion of environmental quality in the area. Moreover, the data contained in Table 1 further indicate that the overwhelming majority (72\%) of respondents were in the age-bracket of 21 - 50 years; this shows that besides being females, majority of respondents have what it takes in terms of energy and doggedness to play a proactive role in issues relating to participatory solid waste management projects in the Bawku Municipality. This finding therefore calls for the need to devote a crucial role to women in the management and control of urban environment in the Municipality.

\subsection{Components of Solid Waste Generated in the Municipality}

Table 5 shows the findings on the major components of the municipal waste stream. The data contained therein are consistent with previous reports on solid waste characterization in Metropolitan, Municipal, and District Assemblies in Ghana as published by [25] [23] and [26]. These results are also in line with previous research which indicates that the highest component of wastes generated in developing nations consist of organic materials [23]. The considerable proportion of plastics in the municipal waste stream could be explained by the increasing use of plastic products in packaging and by the fact that plastics are also being used in Ghana as stretched high density polyethylene (HDPE) in sachet water packaging, polyethylene terephthalate (PET) bottles for bottling drinks and water, low density polyethylene (LDPE) and polystyrene (PS) as bags [25]. From the data it appears that the sizable fraction of plastic waste is an indication of the fact that with the setting up of many plastic industries in Ghana, the generation of plastic waste is likely to increase over time thereby rendering the current challenges regarding plastic waste management in the country severe. The study also revealed that Management Department of the Municipal Assembly and Zoomlion Ghana Limited lacked quantitative data on the amount of waste generated in the municipality. This finding substantiates earlier studies which established that the required fundamental statistics on household waste are lacking in developing countries [27]; and that Ghana is no exception of this data deficit problem [25]. Hence, this situation calls for an in-depth assessment of the quantitative aspect of solid waste being generated in Metropolitan, Municipal and District Assemblies in the country.

\subsection{Respondents' Knowledge and Perceptions of the Waste Management System in the Municipality}

The lack of access to information on solid waste management and sanitation in the municipality by a good majority of the respondents (67\%) as shown in Table 2 
Table 2. Respondents' perceptions of the waste management system in the Municipality.

\section{Variable Respondents \%}

Level of accessibility to information on solid waste management (SWM)/sanitation in the Municipality

Access to information

No access to information

Means by which information on solid waste management/ sanitation was obtained

Parents/relatives

School

8

Mass media

Health/sanitation workers

Respondents' involvement in educating household on SWM/ sanitation

Respondents educate their households on sanitation/SWM $\quad 45$

Respondents do not educate their households on sanitation/SWM

Respondents' perception on who is responsible for managing waste and maintaining the surroundings clean

$$
\text { Every individual }
$$

The Bawku Municipal Assembly (BMA) $\quad 44.67$

Both inhabitants and the BMA

Other 10

Respondents' perception of the importance of work of the waste management personnel in the Municipality

Work carried out by waste management personnel is important $\quad 71$

Work carried out by waste management personnel is not important 29

Respondents' preparedness to make land available for construction of solid waste disposal site in the Municipality

Respondents are prepared

Respondents are not prepared

Reasons for respondents' unpreparedness to make land available for construction of solid waste disposal site in their neighbourhood

Fear of disease outbreak and pollution

Method of collection of household waste in the Municipality

Door-to-door collection by Zoomlion

Shared container (skip)

Other

Person responsible for conveying household solid waste to the dumping site

Household mature people

Household children

Door-to-door collectors

Other

Time used by respondents to dispose of their wastes at skip sites

$\begin{array}{ll}5-10 \text { minutes } & 12 \\ 11-15 \text { minutes } & 32 \\ 16-20 \text { minutes } & 28 \\ 21-25 \text { minutes } & 16 \\ \text { More than } 25 & 12\end{array}$

Availability of communal containers (skips) in communities

Skips are available $\quad 37$

Skips are unavailable $\quad 63$

Place where households dispose of their waste

Backyard 
Respondents' perception about the distance between the nearest skip and their houses

The distance is inconvenient

Respondents' perception of the effectiveness of waste management in the Municipality

Waste management is effective

Waste management is ineffective

Type of storage receptacles used by households for storing waste

Used basket/bucket without cover

Used basket/bucket with cover22

Plastic bin without cover

Plastic bin with cover

Other

Frequency at which households dispose of their waste

Once in a week

Twice in a week

Every two weeks

Other

could be attributed to the inability of the Municipal Assembly and waste management institutions to carry out adequate public awareness and education by means of workshops, durbars, or other mediums of communication on the importance of proper waste management and sanitation in the municipality. This situation could have serious adverse effects on solid waste management system and activities in the area, as the inadequate knowledge of the residents thereof and the lack or little participation of the people therein could render the underlying objectives of these activities unachievable. The study finding and resultant inference as stated above are a clear indication that public awareness and community participation would assist in obtaining guidance in carrying out strategic planning of SWM [28]. Hence the importance for participating communities in the municipality to understand how good solid waste management can be achieved and can benefit their health [29]. The data contained in Table 2 also showed that a good number of respondents (44.67\%) developed a perception that it was the sole responsibility of the Bawku Municipal Assembly (BMA) to manage waste and maintain the urban environment clean. This finding confirms a previous report by [30] which indicates that with the establishment of the Waste Management Department (WMD) of metropolitan and municipal assemblies, the public tend to have the view that the WMD should be solely responsible for managing waste instead of it being a shared responsibility. This perception is also in agreement with previous reports which pointed out that it is generally regarded that waste management is the sole duty and responsibility of lo- 
cal authorities, and that the public is not expected to contribute [31]. Hence, the study finding re-echoes the need for public awareness and strong community participation in issues relating to waste management and environmental quality in the municipality. Indeed, several authors have buttressed this argument by indicating that the operational efficiency of solid waste management depends upon community awareness and the active participation of both the municipal agency and the citizens [32]. The ensuing inference is that, the lack of a participatory approach in addressing problems relating to waste management and sanitation in the Bawku Municipality could trigger societal apathy for contributing towards finding solutions to these problems [33] [34]. This point is underpinned by findings in this study (Table 2) which showed that $58 \%$ of respondents were not prepared to make land available for construction of solid waste disposal sites in the municipality for fear of disease outbreak and pollutions. This attitude could be attributed to the perception that the environmental control systems and evaluation of the real impacts of solid waste management in developing countries are lacking [35] [36]. Once more, this situation supports the need for public consultation and education on health hazards associated with domestic solid waste disposal sites in the municipality and the remedial measures and mechanisms put in place by municipal waste management institutions to minimise them. This approach would allay the concerns of the people and lessen their opposition to establishing waste disposal sites in the area.

\subsection{Waste Collection System and the Attitudes of the People towards It}

Table 2 also shows the findings on the waste collection system in the Bawku municipality. The data contained in Table 2 revealed a number of problems such as the unavailability of skips in some communities, the long distance between the nearest skip and people's houses, and the dissociation of an important segment of the sample of respondents (34\%) from the two methods of waste collection in the municipality as they had their own way of dealing with the waste generated in their houses. With regard to the unavailability of skips and the inadequate skip ratio to the population which was found to be 1:3136 (as opposed to the acceptable standard of 1:700 as indicated by Zoomlion company limited), it appeared that the average population a skip served was 4 times larger than the standard maximum population a skip was supposed to serve. This situation coupled with the other two problems associated with the waste collection system mentioned above could explain why a good many respondents resorted to disposing of their waste at their backyards, the roadside, open spaces, or nearby gutters. This situation was exacerbated by the fact that $42.7 \%$ of respondents had their wastes conveyed to the collection sites by their children who occasionally dumped the wastes at unauthorized places or at the foot of skips rather than inside. These challenges were also aggravated by the high frequency (once and twice in week) at which $78 \%$ of respondents disposed of their household waste, and the untimely removals of communal containers by the municipal waste 
management institutions leading to skips overflowing with waste and the entire locations strewn with piles of refuse. The problem associated with these insanitary and unsightly scenes is that these unattended wastes were scattered back across the urban space through the wind whose action becomes severe particularly during the harmattan months of December to February and the period coinciding with the onset of rains. The data contained in Table 2 also indicated that $44.67 \%$ of respondents stored the household wastes within their house premises in buckets, baskets and bins devoid of protective covers for four to seven days before dumping them. This situation, coupled with the insanitary conditions associated with waste collection and untimely removals of communal containers, could lead to the proliferation of disease-carrying pests and create grounds for serious public and environmental health hazards as previously reported by [14]. This argument is buttressed by a study conducted by [23] which indicates that a high percentage of workers who handle refuse, and of individuals who live near or on disposal sites, are infected with gastrointestinal parasites, worms, and related organisms; and that contamination of this kind is likely at all points where waste is handled. The same study also reported that these disease-carrying pests can transmit various pathogenic agents such as amoebic and bacillary dysenteries, typhoid fever, salmonellosis, various parasitoses, cholera, yellow fever, plague, and others.

The findings on the door-to-door waste collection method (Table 2), specifically on the perceived exorbitant monthly fees charged by Zoomlion Ghana Ltd for collecting wastes from subscribers' properties, and the complaints about the irregular collection of wastes from their properties by Zoomlion were consistent with findings obtained from a previous study conducted by [37] which indicated that the services being provided by the waste management company Zoomlion Ghana Ltd were characterised by irregularity and challenges leading to waste piling up in homes; a situation which finally coerced subscribers to resort to burning their wastes as a way of getting around this problem. These facts, coupled with the low monthly income level (GHథ 200 - GH\$400) of the majority of respondents (55.33\%) as shown in Table 2, might have accounted for the low public subscription to the Zoomlion waste collection services in the municipality. This inference re-echoes a statement made by [37] which asserts that the fees charged by Zoomlion Ghana Limited deter some households from patronizing this service making these households to resort to the use of sub-standard and uncovered waste containers for storing waste and dispose of their solid waste in environmentally unfriendly manner. Indeed, previous studies buttressed these assertions by pointing out that the system of unit fees for waste removal works well and represents sound practice when individuals want to get rid of their waste and can afford the fees; and that it works poorly when people are too poor to pay fees, when the fees are simply too high, or when there are ready alternatives and no controls for disposing of wastes, such as by dumping the wastes along roads and in open drains or by throwing them into the countryside or burning them [23] [14]. It is in the light of the above described factors that be- 
devilled the waste collection and disposal system in the Bawku Municipality that two thirds of the sample of respondents perceived the waste management in the area as ineffective.

\subsection{Waste Transportation and Final Disposal Methods in the Bawku Municipality}

The study results revealed that mechanical and manual means of waste transportation consisting of skip loader trucks and tricycles respectively were used by the waste management institutions in the Bawku Municipality (Table 4). Previous studies have reported these methods of waste transportation in other towns and cities in Ghana [16] [37] and other developing countries [5]. The problems regarding these means of transport in relation to proper waste management service delivery in the area were the inadequate number of skip loaders and tricycles and the cost of running and maintaining these vehicles vis-à-vis the limited available resources for managing them. Besides, like in other municipal and metropolitan assemblies across the country, there were problems regarding the easy access to the collection sites as a result of the poor nature of roads which becomes worst during the rainy season and the improper planning of the urban area. These challenges explained the rationale behind the irregular removals of communal containers and waste bins from communal collections sites and subscribers' properties; a situation which resulted in communal containers overflowing with waste and waste piling up across the collections sites unattended to, and indiscriminate dumping and burning of waste across the urban area. These facts are substantiated by previous researchers who further emphasised the public and environmental health hazards associated with these waste management deficiencies by indicating that improper waste management activities can increase disease transmission [14] [23], contaminate ground and surface water [38], release greenhouse gases and other air pollutants [20], damage ecosystems, and discourage tourism and other businesses [39]. The study revealed that the final disposal of waste was effected at the municipal landfill site which is located about three kilometres away from Bawku central town centre (Figure 1). This method of waste disposal is reported to be common in other cities and towns in Ghana and in most developing countries across the globe [12] [37]. If previous research has proven that this option is the recommended choice for solid waste disposal for the metropolitan and municipal areas, landfill sites that meet engineering requirements in Ghana are few [12]. This finding was consistent with the study results which revealed that the Misiga landfill site had no cell planning and proper waste compaction and regular cover of waste with clay or soil to reduce odours and keep out pests. Besides, the facility had no leachate and gas collection and management equipment and was accessible by scavengers as it was not properly fenced and guarded. As reported by [14] and [15], these facts are a clear indication that like in other part of the country the Misiga landfill site did not meet the required standard and hence posed serious public health hazards to residents in the area and its surrounding communities through polluted air and 
disease carrying pests. This observation is in consonance with the study finding which showed that $58 \%$ of respondents were not prepared to make land available for construction of final disposal sites in the municipality for fear of disease outbreak and pollutions.

\subsection{Waste Management Institutions in the Municipality and Factors Militating against Their Efficiency}

It is asserted that the participation of the private sector companies such as Zoomlion Ghana Limited in the collection, transportation and disposal of municipal solid waste was necessitated by the poor quality of waste collection and disposal services that characterised the waste management system in the country which used to be under the full responsibility of the metropolitan, municipal and district assemblies [37] [40]. It is posited that, the emergence of the partnership between the public and private sector in the area of solid waste management in general is as a result of the advent of neo-liberal doctrine which saw a reduction of state control coupled with austerity and structural adjustment policies and pressures from multilateral financial institutions which most governments, especially in developing countries have to comply with by cutting down on public expenditures [23] [39]. These factors coupled with pressures from civil society groups on governments to limit taxes, have increasingly focused governments' attentions on identifying specific revenue sources for waste management. This has led to a series of innovations relating to fees and charges for waste collection and disposal by getting households and other waste generators to pay directly for their own waste removal on the basis of how much waste they are setting out [23]. It therefore appears that the municipalities have failed to manage solid waste due to financial and technical factors; and that the involvement of the private sector is a factor that could improve the efficiency of the system [33]. The question then arises whether a synergy in the form of partnership between the two sectors may be achieved or not to deliver better SWM services? [26]. In response to this question in relation to this research, the study data as displayed in Table 3 and Table 4 revealed that the municipal waste management institutions were faced with financial difficulties, understaffing and poor logistics, and social impediments. These findings are the exact reflection of findings reported by several researchers [41] [42]. As regards the financial problems, previous research has indicated that municipalities have failed to manage solid waste due to financial factors. The study result could be explained by the huge expenditure needed to provide the delivery of proper waste management services in the municipality [33], the absence of financial support, limited resources, the unwillingness of the users to pay for the service [42] and lack of proper use of economic instruments. The financial difficulties faced by the Bawku Municipal Assembly are a clear indication that the Bawku municipality and indeed other municipal and metropolitan assemblies across the country need to evolve the required strategic economic instruments that will enable them to marshal the needed financial resources to finance solid waste management. For without 
Table 3. Composition of technical staff of waste management institutions in Bawku Municipality.

\begin{tabular}{|c|c|c|c|c|}
\hline Institution & Personnel & Qualification & Number available & Number needed \\
\hline \multirow{5}{*}{ Zoomlion } & Coordinator & BA Social Sciences & 1 & 1 \\
\hline & Supervisor & "A" level Certificate & 3 & 9 \\
\hline & Mechanics & Technician II & 2 & 10 \\
\hline & Drivers & Motor Vehicle Technician II & 2 & 12 \\
\hline & General Workers & BECE & 343 & 1000 \\
\hline \multirow{5}{*}{ WMD/EHSU } & Director & MA Environmental Management & 1 & 1 \\
\hline & Principal Environmental Health Officers & Diploma Environmental Health & 7 & 10 \\
\hline & Technical Supervisors & Certificate & 5 & 10 \\
\hline & Supervisors & Certificate & 11 & 18 \\
\hline & General Workers & BECE & 15 & 40 \\
\hline
\end{tabular}

Source: WMD and Zoomlion Ghana Ltd, 2014.

Table 4. Equipment base of waste management institutions (WMD and Zoomlion).

\begin{tabular}{|c|c|c|c|c|c|c|}
\hline Equipment & $\begin{array}{l}\text { WMD (number } \\
\text { available) }\end{array}$ & $\begin{array}{l}\text { Number needed } \\
\text { by WMD }\end{array}$ & $\begin{array}{c}\text { ZoomLion (number } \\
\text { available) }\end{array}$ & $\begin{array}{l}\text { Number needed } \\
\text { by Zoomlion }\end{array}$ & $\begin{array}{c}\text { Total } \\
\text { available }\end{array}$ & $\begin{array}{c}\text { Total needed by } \\
\text { WMD and Zoomlion }\end{array}$ \\
\hline Dustbins & 40 & 500 & 100 & 1000 & 140 & 1500 \\
\hline Skips & 11 & 30 & 20 & 50 & 31 & 80 \\
\hline Motor tricycles & & 40 & 36 & 120 & 36 & 160 \\
\hline Graders & 1 & 3 & & 2 & 1 & 5 \\
\hline Skip Loaders & 1 & 3 & 2 & 6 & 3 & 9 \\
\hline Compaction trucks & & 2 & & 2 & & 4 \\
\hline Bulldozers & 1 & 3 & & 1 & 1 & 4 \\
\hline
\end{tabular}

Source: WMD and Zoomlion Ghana Ltd, 2014.

Table 5. Major components of solid waste generated in the Bawku Municipality.

COMPONENTS

Paper

Organic (left-over foods, rotten foodstuffs, peels from yam, and fruits)

Plastic

Textiles

Metal

Leather

Glass

Inert

Total
PERCENTAGE

14.56

55.62

11.96

1.26

5.01

1.64

4.74

5.21

100

Source: Field survey, 2015.

adequate funds, the requisite remedial actions towards addressing the problem of waste management in cities and towns across the country will be elusive. 
These arguments are buttressed by previous authors who reported that in developing countries, SWM is often under-funded due to a combination of inadequate resources from municipal tax revenues, insufficient user fees, and the mismanagement of funds [43] [44]. As displayed in Table 3 and Table 4 the study results showed that the Waste Management and Environmental Health Department of the Municipal Assembly and Zoomlion Ghana Limited were bedevilled by understaffing (limited number of workers especially lack of technical staffs) and poor logistics (lack or inadequate number of trucks, skips, litter bins, graders and bulldozers) in the delivery of their services. With regard to the social constraints that exacerbate the problems faced by waste management institutions in the municipality, the following impediments were pointed out by the Waste Management Department of the Municipal Assembly and Zoomlion Ghana Ltd:

- Bad perceptions and attitudes of majority of residents vis-à-vis the municipal waste management system.

- Indiscriminate disposal of waste by most residents.

- Lack of law enforcement to punish offenders who practised indiscriminate waste disposal.

- Employing people who do not have the required qualification, and difficulty in disciplining non-performing staffs due to political interferences.

The problem regarding the bad perceptions and attitudes of majority of households towards waste management in the municipality is consistent with the study findings as presented in Section 3.2 and captured. Once more, this situation could be blamed on the lack of public education and knowledge on issues relating to waste management and lack or little participation of the people in the municipal solid waste management system. The study result is a clear indication that the structure and functioning of SWM systems are founded on the behaviour patterns and underlying attitudes of the population - factors that are shaped by the local cultural and social context [45]. The fact that most of the residents resorted to indiscriminate disposal of waste is not a surprise, insofar as the municipal waste management institutions were bedevilled by financial difficulties, understaffing and poor logistics which led to inadequate supply of communal containers and dustbins, irregular collection of wastes from subscribers' properties, and untimely removals of communal containers for final disposal of waste. The data elicited from the interviews revealed that the other contributory factor in the indiscriminate disposals of waste by most of the residents in the municipality was the lack of law enforcement. This finding supports the fact that the institutional aspects of waste management also include the current and future legislation, and the extent to which it is enforced [44]. Hence, the lack of law enforcement vis-à-vis the indiscriminate disposal of solid waste in the Bawku municipality and indeed other cities and towns across the country echoes the argument that there seems to be general consensus that weak institutions are a major issue in emerging and developing countries [46]; and that enforcement of laws governing regular SWM activities is often poor, resulting in improperly 
functioning SWM systems [43] [47]. The interviewees of the Waste Management Department/Environmental Health and Sanitation Unit and Zoomlion Ghana Ltd also bemoaned some political influences in the recruitment of their employees which compelled them to employ people who lacked the required professional qualification and skills and further precluded them from taking disciplinary sanctions against non-performing employees. These facts are supported by findings from previous research which indicate that in developing countries, political jostling for power means that local authorities base decision-making on the interests of their parties [47]; and that government bodies maintain inflated workforces for political reasons, which consume much-needed funds [47].

\section{Conclusions and Recommendations}

The results of this study indicate that the waste management system in the Bawku Municipality is bedevilled by many challenges which need to be addressed holistically so as to achieve the core objectives of waste management i.e. the protection of public health and the quality of the environment. The key findings regarding these challenges are as follows:

1) The functioning of the waste management system in the Municipality was seriously handicapped by the lack of public awareness on issues regarding waste management and the lack of a participatory approach that makes the people of the area an integral and active stakeholder in waste management decision-making process and activities. This situation has led a good majority of the people in the Municipality to develop bad perceptions and attitudes vis-à-vis the municipal waste management system, particularly by disposing of their wastes indiscriminately and by perceiving waste management as the exclusive responsibility of the local government.

2) The waste management in households was chiefly women's job. This is an indication that women play a pivotal role in waste collection and should therefore be given a status of key stakeholder in the development and implementation of a strategic plan for successful solid waste management and promotion of environmental quality in the area.

3) The study revealed the lack of quantitative data on the volume of waste generated in the Municipality. This situation adversely affects the short-term and long-term planning of waste management in the area, particularly in terms of mobilising the required financial resources and logistics so as to ensure the waste management system and efficiency keep pace with the future volumes of waste stream.

4) A good majority of households used improper waste storage receptacles in the form of buckets, baskets and bins without lids to store waste. This situation poses serious public and environmental health hazards as the uncovered wastes served as proliferation grounds for disease vectors.

5) The municipal waste collection and transport systems were riddled with numerous problems, namely the inadequate supply of waste collection containers, the existence of a weak waste transportation system and a low patronage 
of the door-to-door collection which was deemed unaffordable by majority of residents and the poor nature of roads which hindered the waste collection services. These challenges greatly accounted for the indiscriminate disposal of waste in the Municipality and the low performance rating of the waste management system which was perceived by majority of households as inefficient.

6) The municipal landfill which was located about three kilometres away from the Bawku Township in Misiga did not meet the required standard. The landfill site had no cell planning and proper waste compaction, and there was no regular cover of waste with clay or soil to reduce odours and keep out pests. The facility had no leachate and gas collection systems, and was readily accessible by scavengers. This situation posed serious public health hazards to residents in the area and neighbouring communities.

7) The two main institutions in charge of managing solid waste in the Municipality i.e. the Municipal Waste Management Department and the private company Zoomlion Ghana Limited were faced with financial difficulties, understaffing and poor logistics, and social constraints including political interferences in the recruitment of the workforces. These factors seriously handicapped the performance of the waste collection, transport and disposal services and the efficiency of the whole system of managing waste.

The findings on the factors that adversely affect the waste management system in the Bawku Municipality could feed into the development of an all-inclusive strategic plan for effective solid waste management in the Municipality.

\section{References}

[1] Pacione, M. (2005) Urban Geography: A Global Perspective. 2nd Edition, Routedge, Taylor \& Francis Group, London and New York.

[2] Anomanyo, D.E. (2004) Integration of Municipal Solid Waste Management in Accra, Ghana: Biofactor Treatment Technology as an Integral Part of the Management Process. Presented to Lund University, Sweden.

[3] Tacoli, C. (2012) Urbanization, Gender and Urban Poverty: Paid Work and Unpaid Care Work in the City. International Institute for Environment and Development, United Nations Population Fund, London, UK.

[4] Yousif, D.F. and Scott, S. (2007) Governing Solid Waste Management in Mazatenango, Guatemala: Problems and Prospects. International Development Planning Review, 29, 433-450. https://doi.org/10.3828/idpr.29.4.2

[5] Nabegu, A.B. (2010) An Analysis of Municipal Solid Waste in Kano Metropolis, Nigeria. Journal of Human Ecology, 31, 111-119.

[6] Nagabooshnam, J.K. (2011) Solid Waste Generation and Composition in Gaborone, Botswana, Potential for Resource Recovery. Master Thesis, Department of Management Engineering, Linkoping University, Sweden.

[7] Okot-Okumu, J. (2012) Solid Waste Management in African Cities-East Africa, Waste Management-An Integrated Vision. InTech.

[8] Valkenburg, C., Walton, C.W., Thompson, B.L., Gerber, M.A., Jones, S. and Stevens, D.J (2008) Municipal Solid Waste (MSW) to Liquid Fuels Synthesis, Volume 1: Availability of Feedstock and Technology. PNNL 18144, Pacific Northwest National Laboratory, Richland, WA. 
[9] Freduah, G. (2004) Problems of Solid Waste Management in Nima, Accra. University of Ghana, Legon.

[10] Cooper, J. (1999) The Challenges of Environmental Management in Urban Areas. Aldershot and Vermont, Ashgate.

[11] Songsore, J., Nabila, J.S., Yangyuoru, Y., Amuah, E., Bosque-Hamilton, E.K., Etsibah, K.K., Jan-Eric, G. and Jacks, G. (2005) State of the Environmental Health Report of the Greater Accra Metropolitan Area (GAMA). Ghana University Press, Accra.

[12] Mensah, A. and Larbi, E. (2005) Solid Waste Disposal in Ghana. WELL FACT SHEET Regional Annex.

[13] Hardoy, J.E., Mitlin, D. and Statterthwaite, D. (2001) Environmental Problems in an Urbanizing World: Finding Solutions in Cities in Africa, Asia and Latin America. 2nd Edition, Earthscan, London and Stirling, VA.

[14] Oteng-Ababio, M., Argurello, J.E.M. and Gabbay, O. (2013) Solid Waste Management in African Cities: Sorting the Facts from the Fads in Accra, Ghana. Habitat International, 39, 96-104.

[15] Owusu-Sekyere, E., Osumanu, I.K. and Yaro, J.A.D. (2013) Landfill in the Kumasi Metropolitan Area of Ghana. International Journal of Current Research, 2, 87-96.

[16] Ampofo, S., Sackey, I. and Ampadu, B. (2016) Landscape Changes and Fragmentation Analysis in a Guinea Savannah Ecosystem; Case Study: Talensi and Nabdam Districts of the Upper East Region, Ghana. Journal of Geography and Geology, 8, 41-54. https://doi.org/10.5539/jgg.v8n1p41

[17] (GSS) Ghana Statistical Service (2012) 2010 Population and Housing Census: District Analytical Report. Bawku Municipality.

[18] Adugbire, S.A., Kuma, J.S., Suglo, R.S. and Nartey, R.S. (2010) Community-Based Management of Boreholes in the Talensi-Nabdam District in the Upper East Region, Ghana: Problems and Solutions. European Journal of Scientific Research, 46, 643-653.

[19] Bryman, A. (2008) Social Research Methods. 3rd Edition, Oxford University Press, Oxford.

[20] Nordtest (1995) Solid Waste, Municipal: Sampling and Characterization. Nordtest method NT, Finland.

[21] Gomez, G., Meneses, M., Ballinas, L. and Castells, F. (2008) Characterization of Urban Solid Waste in Chihuahua, Mexico. Waste Management, 28, 2465-2471.

[22] Scheinberg, A., Muller, M. and Tasheva, E.L. (1999) Gender and Waste: Integrating gender into Community Waste Management: Project Management Insights and Tips. Urban Waste Expertise Programme (UWEP) Working Document 12, Gouda, the Nederlands.

[23] UNEP (United Nations Environment Programme) (2005) Solid Waste Management. Vol. I.

http://www.unep.or.jp/ietc/publications/spc/solid waste management/Vol I/Binde $\underline{\text { r1.pdf }}$

[24] Eugene, A., Günter, B. and Lilian, N. (2013) The Evolving Role of Women in Sustainable Waste Management in Developing Countries-A Proactive Perspective? International Conference on Integrated Waste Management and Green Energy Engineering (ICIWMGEE2013), Johannesburg, South Africa, 15-16 April 2013.

[25] Miezah, K., Obiri-Danso, K., Zsófia, K., Fei-Baffoe, B. and Mensah, M.Y. (2015) Municipal Solid Waste Characterization and Quantification as a Measure towards Effective Waste Management in Ghana. Waste Management, 46, 15-27. 
[26] Ahmed, S.A. and Ali, M. (2004) Partnerships for Solid Waste Management in Developing Countries: Linking Theories to Realities. Habitat International, 28, 467- 469.

[27] Buenrostro, O., Bocco, G. and Vence, J. (2001) Forecasting Generation of Urban Solid Waste in Developing Countries-A Case Study in Mexico. Journal of the Air \& Waste Management Association, 51, 86-93. https://doi.org/10.1080/10473289.2001.10464258

[28] World Bank (2004) Social Assessment and Public Participation in Municipal Solid Waste Management.

http://siteresources.worldbank.org/INTUSWM/Resources/463617-1202332338898/s ocialassesstoolkit.pdf

[29] WHO (2005) Management of Solid Health-Care Waste at Primary Health-Care Centres. www.who.int/water_sanitation health/publications/manhcwm.pdf

[30] Songsore, J. and McGranaham, G. (1993) Environment, Wealth and Health: Towards an Analysis of Intra-Urban Differentials within the Greater Accra Metropolitan Area. Stockholm, Sweden. Stockholm Environmental Institute.

[31] Vidanaarachchi, C.K., Yuen, S.T.S. and Pilapitiya, S. (2006) Municipal Solid Waste Management in the Southern Province of Sri Lanka: Problems, Issues and Challenges. Journal of Waste Management, 26, 920-930.

[32] Lilliana, A., Guerrero, G.M. and William, H. (2012) Solid Waste Management Challenges for Cities in Developing Countries. Waste Management, 33, 220-232.

[33] Sharholy, M., Ahmad, K., Vaishya, R.C. and Gupta, R.D. (2007) Municipal Solid Waste Characteristics and Management in Allahabad, India. Journal of Waste Management, 27, 490-496.

[34] Moghadam, M.R.A., Mokhtarani, N. and Mokhtarani, B. (2009) Municipal Solid Waste Management in Rasht City. Iran Journal of Waste Management, 29, 485-489.

[35] Matete, N. and Trois, C. (2008) Towards Zero Waste in Emerging Countries-A South African Experience. Journal of Waste Management, 28, 1480-1492.

[36] Asase, M., Yanful, E.K., Mensah, M., Stanford, J. and Amponsah, S. (2009) Comparison of Municipal Solid Waste Management Systems in Canada and Ghana: A Case Study of the Cities of London, Ontario, and Kumasi, Ghana. Journal of Waste Management, 29, 2779-2786.

[37] Twumasi, A.S. and Akwasi, K.E. (2014) Solid Waste Management in Urban Areas of Ghana: Issues and Experiences from Wa. Journal of Environment Pollution and Human Health, 2, 110-117.

[38] Ogawa, H. (2005) Sustainable Solid Waste Management in Developing Countries. http://www.gdrc.org/

[39] Zeiss, C.A. (1998) Sitting Waste Disposal Facilities in Host Communities: Impacts and Acceptance. $\mathrm{PhD}$, JWA.

[40] World Bank (1996) Urban Environmental Sanitation Project Staff Appraisal Report. http://documents.worldbank.org/curated/en/797301468770981963/Ghana-Urban-E nvironmental-Sanitation-Project

[41] Burntley, S.J. (2007) A Review of Municipal Solid Waste Composition in the United Kingdom. Journal of Waste Management, 27, 1274-1285.

[42] Sujauddin, M., Huda, M.S. and Rafiqul Hoque, A.T.M. (2008) Household Solid Waste Characteristics and Management in Chittagong, Bangladesh. Journal of Waste Management, 28, 1688-1695.

[43] Coffey, M. and Coad, A. (2010) Collection of Municipal Solid Waste in Developing Countries. UN-HABITAT, Malta.

[44] Zurbruegg, C. (2003) Solid Waste Management in Developing Countries: A Sour- 
cebook for Policy Makers and Practitioners: EAWAG/SANDEC.

[45] Schübeler, P. (1996) Conceptual Framework for Municipal Solid Waste Management in Low-Income Countries. In: Wehrle, K. and Christen, J., Eds., UNDP/ UNCHS/ World Bank/SDC Collaborative Programme on Municipal Solid Waste Management in Low-Income Countries, SKAT, St. Gallen, Switzerland.

[46] Wilson, D.C., Araba, A., Chinwah, K. and Cheeseman, C.R. (2009) Building Recycling Rates through the Informal Sector. Journal of Waste Management, 29, 629635.

[47] Henry, R.K., Yongsheng, Z. and Jun, D. (2006) Municipal Solid Waste Management Challenges in Developing Countries-Kenyan Case Study. Journal of Waste Management, 26, 92-100.

Submit or recommend next manuscript to SCIRP and we will provide best service for you:

Accepting pre-submission inquiries through Email, Facebook, LinkedIn, Twitter, etc. A wide selection of journals (inclusive of 9 subjects, more than 200 journals) Providing 24-hour high-quality service User-friendly online submission system Fair and swift peer-review system Efficient typesetting and proofreading procedure Display of the result of downloads and visits, as well as the number of cited articles Maximum dissemination of your research work

Submit your manuscript at: http://papersubmission.scirp.org/ Or contact ijg@scirp.org 